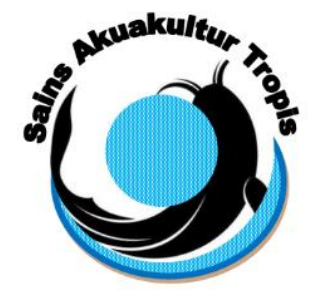

\author{
Jurnal Sains Akuakultur Tropis \\ Departemen Akuakultur \\ Fakultas Perikanan dan Ilmu Kelautan - Universitas Diponegoro \\ JI. Prof. Soedarto, SH, Tembalang, Semarang 50275 \\ Telp. (024) 7474698, Fax.: (024) 7474698 \\ Email: sainsakuakulturtropis@gmail.com, sainsakuakulturtropis@undip.ac.id
}

\title{
PENAMBAHAN KANDIDAT PROBIOTIK Bacillus methylothrophicus SECARA BERKALA PADA MEDIA PEMELIHARAAN UNTUK PENCEGAHAN INFEKSI BAKTERI Aeromonas hydrophila PADA IKAN NILA (Oreochromis niloticus)
}

\begin{abstract}
Addition of Bacillus methylothrophicus Probiotic Candidate Periodically in Media Culture for The Prevention of Bacterial Infection Aeromonas hydrophila in Tilapia Fish (Oreochromis niloticus)
\end{abstract}

Femy Musthofa Ardy, Desrina*, A.H.Condro Haditomo

Departemen Akuakultur, Fakultas Perikanan dan Ilmu Kelautan,

J1. Prof. Soedarto, SH, Tembalang, Semarang, Jawa Tengah -50275, Telp/Fax. +62247474698

* Corresponding author: rinadesrina@yahoo.com

\begin{abstract}
ABSTRAK
Aeromonas hydrophila adalah bakteri yang menyebabkan penyakit MAS (motile aeromonas septicemia) pada budidaya ikan tawar dan dapat menyebabkan kematian massal dalam waktu cukup singkat pada beberapa spesies termasuk ikan nila. Terdapat beberapa strategi alternatif dalam pencegahan, salah satunya penggunaan bakteri probiotik sebagai agen pengontrol atau pencegahan penyakit ini. Salah satu kandidat probiotik yang telah diidentifikasi secara molekular 16sRNA dan diketahui memiliki kemampuan menghambat bakteri patogen adalah B. methylotrhrophicus. Tujuan dari penelitian ini adalah untuk mengkaji B. methylothrophicus dalam menghambat A. hydrophila pada budidaya Oreochromis niloticus. Penelitian ini terdiri dari uji in vitro dan in vivo yang menggunakan metode ekperimental rancangan acak lengkap dengan 4 perlakuan (kepadatan 1 ikan/l) dan 3 ulangan. Perlakuan terdiri dari campuran A.hidrophila $10^{2} \mathrm{CFU} / \mathrm{mL}$ dengan bakteri B. methylotrophicus $10^{9}$ CFU/mL (a) Tanpa penambahan B. methylotrophicus (b) Penambahan setiap 3 hari, (c) Penambahan setiap 5 hari, (d) Penambahan setiap 7 hari. 120 ikan dengan berat rata-rata 17,5 $\pm 1,9$ g digunakan sebagai hewan uji. Berdasarkan uji in vitro, konsentrasi B.methylotrophicus yang paling kuat untuk menghambat $A$. hydrophila adalah $10^{9} \mathrm{cfu} / \mathrm{mL}$ dengan zona bening $24,9 \pm 4,2 \mathrm{~mm}$. Uji in vivo menunjukkan bahwa penambahan B. methylotrophicus secara berkala tidak berpengaruh nyata terhadap tingkat kelangsungan hidup, akan tetapi dapat memperlambat pertumbuhan A. hydrophila. Perlakuan D menunjukkan tingkat kelangsungan hidup tertinggi $(13,33 \%)$, diikuti oleh perlakuan A $(6,66 \%)$, B (3,33\%), dan C (3,33\%). Hasil ini menunjukkan bahwa B.methylotrophicus dapat memperlambat pertumbuhan $A$. hydrophila secara in vitro, dan mampu meningkatkan SR sebesar $6,66 \%$ pada uji in vivo.
\end{abstract}

Kata kunci: $B$. methylotrophicus, kandidat probiotik, A. hydrophila, O. niloticus, ikan nila

\section{ABSTRACT}

Aeromonas hydrophila is a bacteria that causes of MAS disease (motile aeromonad septicemia) in freshwater fish cultivation and can cause mass death in a fairly short period of time in some species including tilapia. There are several alternative strategies in prevention, one of which is the use of probiotic bacteria as agents for controlling or preventing this disease. One candidate for probiotics that has been molecularly identified as 16sRNA and is known to have the ability to inhibit pathogenic bacteria is B. methylotrhrophicus. The aim of this research was to study B.methylotrophicus in inhibiting A. hydrophila in Oreochromis niloticus culture. This research consisted of in vitro and in vivo test that used experiment method with completely randomized design with 4 treatments (density of 1 fishes/l) and 3 replications. The treatment consisted of a mixture of A. hydrophila $10^{2} \mathrm{CFU} / \mathrm{mL}$ with B. methylotrophicus $10^{9} \mathrm{CFU} / \mathrm{mL}(\mathrm{a})$ without addition of B. methylotrophicus $(b)$ Addition every 3 days, (c) Addition every 5 days, (d) Addition every 7 day. 120 fishes at average weight of 17,5 $\pm 1,9 \mathrm{~g}$ was used as experimental animals. Based on the in vitro test, the most powerful concentration of B. methylotrophicus to 


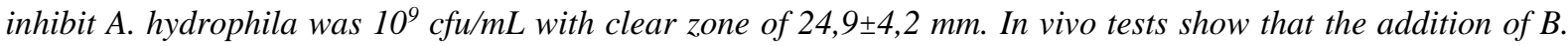
methylotrophicus periodecally does not significantly affect survival rates, but can slow the gowth of A. hydrophila. Treatment $D$ showed the highest survival rate (13.33\%), followed by treatment $A(6.66 \%), B(3.33 \%)$, and $C$ $(3.33 \%)$. These results indicate that B.methylotrophicus can prevent the gowth of A. hydrophila in vitro, and can increase SR by $6.66 \%$ in the in vivo test.

Keywords: B. methylotrophicus, probiotic candidate, A. hydrophila, O. niloticus, survival rate

Article Received: 20-12-2018; Accepted: 09-09-2019

\section{PENDAHULUAN}

Ikan nila (Oreochromis niloticus) merupakan jenis ikan budidaya air tawar yang memiliki nilai ekonomis penting dan merupakan salah satu jenis ikan yang populer di konsumsi di kalangan masyarakat Indonesia. Nilai produksi ikan nila terus meningkat pada tahun 2010 sebesar 491.800 ton dan pada tahun 2012 meningkat sebesar 850.000 ton (KKP, 2013). Dengan semakin meningkatnya komersialisasi dan intensifikasi produksi akuakultur, penyakit dan kerusakan kondisi lingkungan adalah masalah utama pada kegiatan budidaya ikan nila (Das et al., 2017) dan berdampak pada kerugian ekonomi. Salah satu jenis penyakit ikan yang sering dijumpai pada ikan nila dan ikan air tawar pada umumnya di seluruh dunia adalah penyakit bacterial yang disebabkan oleh bakteri Aeromonas hydrophila.

Bakteri A. hydrophila adalah bakteri bersifat oportunistik yakni mampu menimbulkan penyakit apabila ada faktor lain yang mendukung dan dapat menyebabkan kematian pada ikan dalam waktu yang singkat (Garde et al., 2010). A. hydrophila merupakan agensia penyebab penyakit Motile Aeromonas Septicemia (MAS) yang memiliki tanda-tanda berupa terjadinya hemoragi meluas pada permukaan tubuh, pangkal sirip ekor dan operculum,

Berbagai upaya telah banyak dilakukan untuk menanggulangi infeksi A.hydrophila, salah satunya dengan pengobatan menggunakan antibiotik yang sebenarnya dapat membuat bakteri patogen menjadi resisten dan residu pada ikan yang akan berbahaya apabila dikonsumsi manusia. Solusi lain yang dapat digunakan yakni penggunaan bakteri probiotik dan merupakan salah satu pendekatan alternatif yang lebih aman dibandingkan dengan antibiotik atau bahan kimia lain untuk pengendalian pencegahan terjadinya penyakit dalam kegiatan budidaya (Esteban $e t$ al., 2014). Bakteri kandidat probiotik yang berpotensi menghambat pertumbuhan A. hydrophila adalah bakteri Bacillus methylotrophicus yang ditemukan oleh Haditomo et.al. (2017), dengan kode isolat CBL20. B. methylotrophicus mampu secara aktif menghambat bakteri patogen baik Gram positif, maupun Gram negatif (Sharma et al.,2013). Kandungan lipopeptida siklik yang termasuk dalam kelompok surfaktin dan iturin diduga menjadi zat aktif yang menghambat pertumbuhan bakteri patogen (Jemil et al., 2017). Potensi B. methylotrophicus ini masih belum banyak diterapkan pada bakteri patogen ikan, termasuk A. hydrophila pada ikan nila.

Penelitian ini bertujuan untuk mengkaji pengaruh penggunaan bakteri kandidat probiotik dalam media budidaya terhadap gejala klinis, kelulushidupan ikan nila (O. niloticus), dan fluktuasi kepadatan bakteri dalam air budidaya ikan nila (O. niloticus) yang diberi $A$. hydrophila serta untuk mengetahui waktu pemberian terbaik $B$. methylotrophicus secara in vitro dan in vivo dalam menghambat $A$. hydrophila pada media budidaya ikan nila. Penelitian ini dilaksanakan pada bulan Mei sampai Juli 2018 di Laboratorium Kering dan Basah Departemen Akuakultur, Fakultas Perikanan dan Ilmu Kelautan, Universitas Diponegoro, Semarang.

\section{MATERI DAN METODE}

Ikan uji yang digunakan dalam penelitian ini adalah ikan nila (O. niloticus) yang berasal dari Unit Pembenihan Rakyat Mina Muncul (Muncul, Ambarawa, Semarang) dengan padat tebar 1 ekor/L, 10

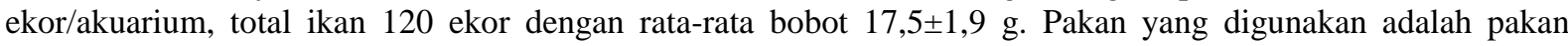
komersil berbentuk pelet dengan kadar protein 35\% diberikan secara at satiation sebanyak 2 kali (pagi dan sore hari) yaitu pukul 08.00 dan 16.00 WIB (Farias et al., 2016).

Bakteri yang digunakan adalah bakteri kandidat probiotik yang diperoleh Haditomo et al.(2017) dengan kode isolat CBL20 yang merupakan hasil screening bakteri lumpur budidaya ikan nila di Boyolali, Jawa Tengah. Bakteri ini telah diidentifikasi berdasarkan analisis sequence 16sRNA dan kemudian membandingkan dengan sequence di NCBI sehingga diperoleh jenis bakteri B. methylotrophicus strain XJAJ2 dengan tingkat homologi 100\%. Bakteri patogen pada penelitian ini adalah Aeromonas hydrophila. Isolat murni A. hydrophila diperoleh dari proses isolasi bakteri pada media budidaya ikan nila yang terjadi kematian masal di Laboratorium Basah Universitas Diponegoro yang telah dilakukan uji biokimia untuk proses identifikasi (Haditomo, 2017).

Media pemeliharaan menggunakan air tawar, berasal dari air pam yang telah diendapkan terlebih dahulu pada bak tandon selama satu minggu dan telah disterilkan menggunakan kaporit cair $10 \mathrm{ppm}$ dan natrium tiosulfat $20 \mathrm{ppm}$. Volume air adalah $10 \mathrm{~L}$ per akuarium. Wadah yang digunakan dalam penelitian ini adalah akuarium dengan ukuran $40 \mathrm{~cm}$ x $30 \mathrm{~cm}$ x 40 cm dengan kapasitas $48 \mathrm{~L}$ air. Jumlah akuarium yang digunakan untuk penelitian ini sebanyak 12 buah dan dilengkapi sistem aerasi. 
Media yang digunakan adalah Tryptic Soy Agar (TSA) untuk proses uji in vitro (Ulkhaq et al., 2014) dan kultur isolat murni. Media selektif Glutamate Starch Phenol (GSP) sebagai media kultur A. hydrophila dan uji pasase. Media TSB (Tryptic Soy Broth) digunakan sebagai media kultur cair.

Prosedur penelitian ini terdiri dari tahap persiapan dan tahap pelaksanaan. Tahap persiapan terdiri dari sterilisasi alat dan bahan, aklimatisasi ikan uji, pembuatan media bakteri, kultur bakteri dan pengganasan bakteri. Alat-alat mikrobiologi disterilkan dengan cara dicuci kemudian autoclave suhu $121^{\circ} \mathrm{C}$ pada tekanan 1 atm selama 20 menit (Andriani, 2016). Alat untuk streak bakteri disterilisasi menggunakan alkohol 70\% kemudian dibakar diatas api bunsen.

Tahap pelaksanaan terdiri dari uji in vitro, uji pendahuluan (penentuan dosis), dan uji in vivo. Uji in vitro yang dilakukan adalah uji zona hambat dengan melihat ada tidaknya zona bening di sekitar kertas cakram dan diukur diameternya. Kertas cakram direndam pada konsentrasi tertentu B. methylotrophicus kemudian ditanam pada media TSA yang sudah dispread A.hydrophila. Pengamatan hasil dilakukan setelah 24 jam.

Uji pendahuluan (penentuan dosis) mengacu pada penelitian Agustina et al., 2018 dilakukan melalui aplikasi $B$. methylotrophicus pada media budidaya ikan nila yang terdapat $A$. hydrophila $10^{2} \mathrm{CFU} / \mathrm{mL}$ dan diamati respon ikan nila selama 14 hari pemeliharaan. Konsentrasi bakteri kandidat probiotik yang diujikan yaitu $10^{7}, 10^{8}$, $10^{9} \mathrm{CFU} / \mathrm{mL}$ sebanyak 4 perlakuan (1 perlakuan kontrol tanpa diberikan bakteri kandidat probiotik) 3 kali ulangan. Kepadatan 1 ekor/L atau 10 ekor per akuarium. Parameter yang diamati adalah kelulushidupan, gejala klinis, profil darah dan jumlah kepadatan bakteri pada media budidaya (Haditomo et al., 2016). Hasil uji pendahuluan terbaik yakni pada perlakuan D dengan SR sebesar 56, 67\%.

Uji in vivo mengacu pada penelitian Agustina et al. (2018). Media budidaya steril disiapkan sebanyak $10 \mathrm{~L}$ per akuarium. Kemudian media diberi A. hydrophila $10^{2} \mathrm{CFU} / \mathrm{mL}$ dan B. methylotrophicus kepadatan $10^{9} \mathrm{CFU} / \mathrm{mL}$ diberikan dengan waktu pemberian yang berbeda yakni setiap 3 hari sekali (b) 5 hari sekali (c) 7 hari sekali (d) dan tanpa diberikan B. methylotrophicus (a). Ikan uji 10 ekor setiap akuarium (padat tebar 1 ekor/L) dimasukkan ke dalam akuarium yang telah diberi bakteri dan diamati selama 21 hari.

Metode yang digunakan adalah eksperimental dengan rancangan acak lengkap (RAL) 4 perlakuan dan 3 ulangan. Penelitian ini menggunakan perlakuan pemberian A. hydrophila $10^{2} \mathrm{CFU} / \mathrm{mL}$ pada media pemeliharaan dan penambahan $B$. methylotrophicus $10^{9}$ dengan waktu pemberian:

Perlakuan A : tanpa diberikan B.methylotrophicus

Perlakuan B : diberikan $10^{9} \mathrm{CFU} / \mathrm{mL}$ setiap 3 hari sekali

Perlakuan C : diberikan $10^{9} \mathrm{CFU} / \mathrm{mL}$ setiap 5 hari sekali

Perlakuan D : diberikan $10^{9} \mathrm{CFU} / \mathrm{mL}$ setiap 7 hari sekali

Ikan diberikan pakan secara at satiation sebanyak 2 kali (pagi dan sore hari) yaitu pukul 08.00 dan 16.00 WIB. Pakan yang digunakan adalah pakan komersil berbentuk pelet dengan kadar protein 35\%, dan selama 21 hari perlakuan tidak dilakukan penyiponan.

\section{HASIL}

\section{Uji In Vitro}

Berdasarkan uji zona hambat, diperoleh hasil yang tersaji pada Tabel 1.

Tabel 1. Diameter zona hambat

\begin{tabular}{|c|c|c|c|c|c|}
\hline \multirow{2}{*}{ No. } & \multirow{2}{*}{$\begin{array}{l}\text { Kepadatan bakteri probiotik } \\
\text { (B.methylotrophicus) CFU/mL }\end{array}$} & \multicolumn{3}{|c|}{ Diameter zona hambat (mm) } & \multirow{2}{*}{ Rata-rata \pm SD (mm) } \\
\hline & & 1 & 2 & 3 & \\
\hline 1 & $10^{3}$ & 7 & 7,2 & 7 & $7,07 \pm 0,12$ \\
\hline 2 & $10^{4}$ & 8 & 8 & 7,2 & $7,73 \pm 0,46$ \\
\hline 3 & $10^{5}$ & 9 & 7 & 8 & $8 \pm 1$ \\
\hline 4 & $10^{6}$ & 8,3 & 8,6 & 8,6 & $8,5 \pm 0,2$ \\
\hline 5 & $10^{7}$ & 12,8 & 14,7 & 18 & $15,2 \pm 2,63$ \\
\hline 6 & $10^{8}$ & 10 & 7 & 7 & $8 \pm 1,7$ \\
\hline 7 & $10^{9}$ & 20,6 & 29 & 25 & $24,9 \pm 4,2$ \\
\hline
\end{tabular}

Gambar hasil uji zona hambat dapat dilihat pada Gambar 1. 


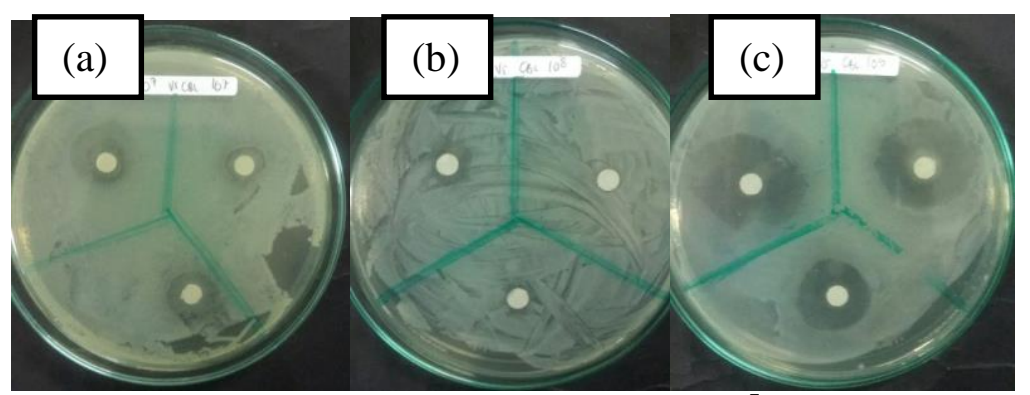

Gambar 1. Diameter zona hambat (a) konsentrasi B. methylotrophicus $10^{7} \mathrm{CFU} / \mathrm{mL}$, (b) B. methylotrophicus $10^{8}$ $\mathrm{CFU} / \mathrm{mL}$, (c) B. methylotrophicus $10^{9} \mathrm{CFU} / \mathrm{mL}$

Rata-rata diameter zona bening yang tertinggi pada kepadatan bakteri B. methylotrophicus $10^{9} \mathrm{CFU} / \mathrm{mL}$ yaitu 24,9 $\pm 4,2 \mathrm{~mm}$. Kepadatan B. methylotrophicus kemudian yang digunakan pada uji in vivo adalah $10^{7}, 10^{8}$, dan $10^{9} \mathrm{CFU} / \mathrm{mL}$.

\section{Kelulushidupan}

Kelulushidupan tertinggi adalah perlakuan D (13,33\%) diikuti oleh A $(6,67 \%)$, dan terendah perlakuan C $(3,33 \%)$ dan B (3,33\%). Penambahan B. methylotrophicus mampu meningkatkan kelulushidupan sebesar 6,66\%. Hasil uji analisis ragam menunjukkan bahwa pemberian bakteri $B$. methylotrophicus pada media budidaya dengan waktu pemberian yang berbeda tidak berpengaruh nyata terhadap kelulushidupan ikan nila (O. niloticus) yang diinfeksi A. hydrophila melalui media budidaya $(\mathrm{P}>0,05)$.

\section{Kelimpahan Bakteri}

Total kepadatan bakteri A. hydrophila dan total kepadatan bakteri pada air media pemeliharaan berdasarkan total plate count metode cawan sebar tersaji pada Gambar 2.

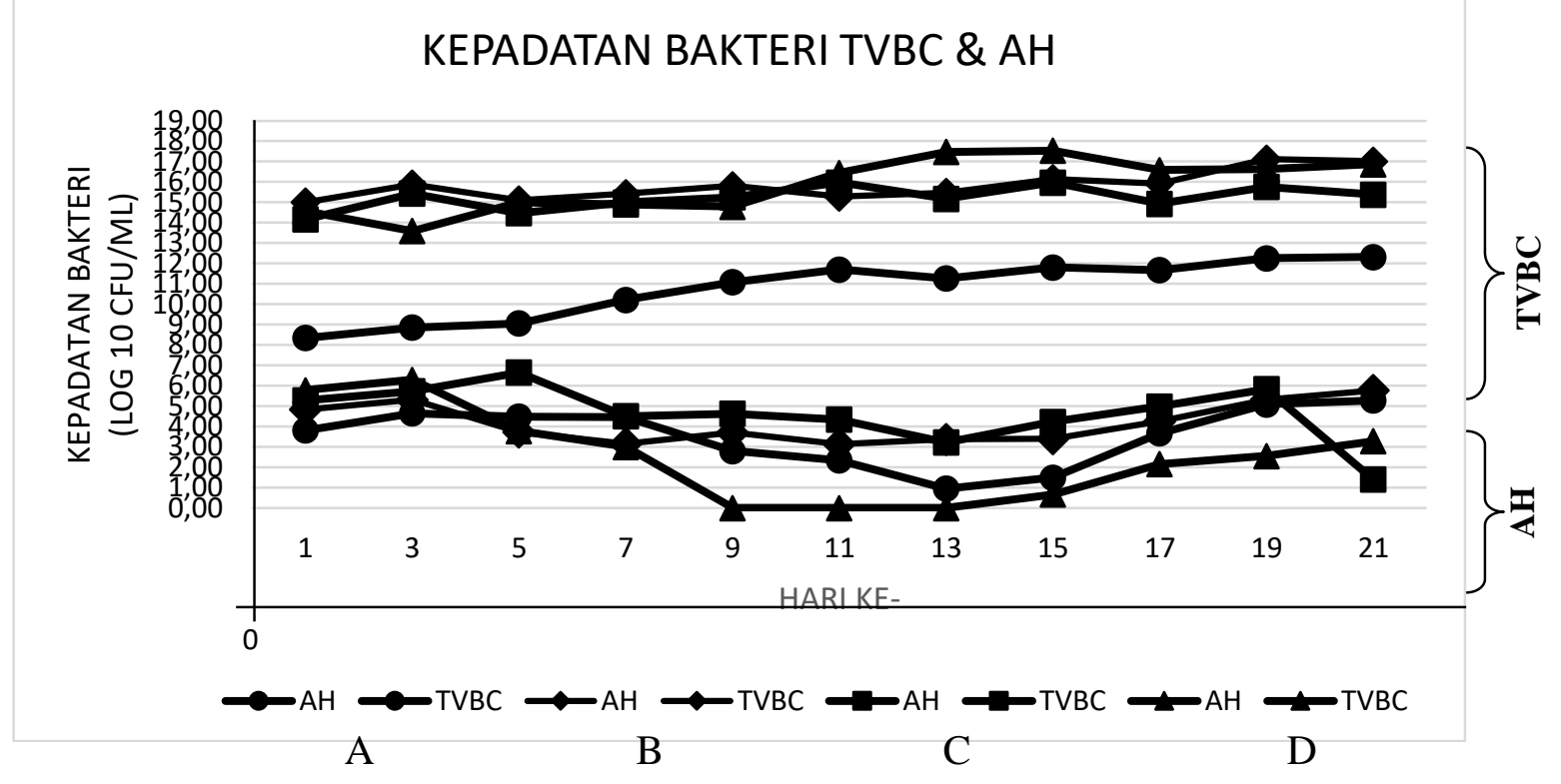

Keterangan:

Gambar 2. Grafik Kepadatan TVBC \& AH

TVBC: total viable bacteria count

AH: Aeromonas hydrophila

A: Perlakuan A (tanpa diberikan B.methylotrophicus)

B: Perlakuan B (diberikan B.methylotrophicus $10^{9} \mathrm{CFU} / \mathrm{mL}$ setiap 3 hari sekali)

C: Perlakuan C (diberikan B.methylotrophicus $10^{9} \mathrm{CFU} / \mathrm{mL}$ setiap 5 hari sekali)

D: Perlakuan D (diberikan B.methylotrophicus $10^{9} \mathrm{CFU} / \mathrm{mL}$ setiap 7 hari sekali)

Total bakteri pada media budidaya rata-rata cenderung meningkat hingga hari ke-11 kemudian mengalami penurunan hingga hari ke-15 dan kemudian cenderung meningkat kembali hingga hari ke-21, untuk kepadatan $A$. hydrophila rata-rata meningkat dari awal hingga hari ke-5 dan semakin menurun hingga hari ke-15, namun hanya pada perlakuan D yang mengalami penurunan jumlah bakteri A. hydrophila yang paling tinggi dan kembali meningkat pada hari ke 16 hingga pada akhir penelitian. Total bakteri pada perlakuan A dan B mengalami peningkatan dari awal penelitian hingga akhir penelitian. Total bakteri akhir penelitian pada perlakuan A adalah $21,25 \times 10^{12} \mathrm{CFU} / \mathrm{mL}$ terdapat bakteri $A$. hydrophila sebanyak 5,9 × $10^{6} \mathrm{CFU} / \mathrm{mL}$, perbandingan bakteri $A$. 
hydrophila dengan bakteri keseluruhan adalah 1:10 . Perlakuan B menunjukan peningkatan jumlah bakteri pada akhir penelitian sebesar 1,6 x $10^{16} \mathrm{CFU} / \mathrm{mL}$ dengan jumlah $A$. hydrophila 5,2 x $10^{6}$ sehingga perbandingan bakteri A. hydrophila dengan bakteri keseluruhan adalah $1: 10^{10}$. Perlakuan $\mathrm{C}$ menunjukkan peningkatan jumlah bakteri pada akhir penelitian (hari ke-21) sebesar $2,5 \times 10^{15} \mathrm{CFU} / \mathrm{mL}$ dengan jumlah A. hydrophila $2,5 \times 10^{1} \mathrm{CFU} / \mathrm{mL}$ perbandingan bakteri $A$. hydrophila dengan bakteri keseluruhan adalah 1:10 ${ }^{13}$. Perlakuan D menunjukkan kenaikan jumlah bakteri pada hari ke-9 hingga akhir penelitian dengan jumlah bakteri total 8,7 x $10^{16} \mathrm{CFU} / \mathrm{mL}$ dengan jumlah A. hydrophila 3,9 × $10^{4} \mathrm{CFU} / \mathrm{mL}$ perbandingan bakteri A. hydrophila dengan bakteri keseluruhan adalah $1: 10^{11}$. Perbandingan jumlah $A$. hydrophila dengan bakteri keseluruhan pada hari ke-1 adalah $1: 10^{9}$ untuk perlakuan D, B sedangkan perlakuan C adalah 1:10 ${ }^{8}$ untuk perlakuan A adalah 1:10 ${ }^{4}$

\section{Gejala Klinis}

Gejala klinis ikan nila selama 21 hari perlakuan tersaji pada Tabel 2.

Tabel 2. Gejala Klinis Perubahan Tingkah Laku dan Morfologi Ikan Nila

\begin{tabular}{|c|c|c|c|c|c|c|c|c|c|c|c|c|}
\hline \multirow{2}{*}{ Hari ke } & \multicolumn{3}{|c|}{$\mathrm{A}$} & \multicolumn{3}{|c|}{ B } & \multicolumn{3}{|c|}{$\mathrm{C}$} & \multicolumn{3}{|c|}{ D } \\
\hline & 1 & 2 & 3 & 1 & 2 & 3 & 1 & 2 & 3 & 1 & 2 & 3 \\
\hline 1 & $\mathrm{a}, \mathrm{c}$ & $\mathrm{a}, \mathrm{c}$ & $\mathrm{a}, \mathrm{c}$ & $\mathrm{a}$ & $\mathrm{a}, \mathrm{c}$ & $\mathrm{a}, \mathrm{c}$ & $\mathrm{a}$ & $\mathrm{a}$ & $a, c$ & $a, c$ & $\mathrm{a}, \mathrm{c}$ & $\mathrm{a}, \mathrm{c}$ \\
\hline 2 & $\mathrm{~b}, \mathrm{c}, \mathrm{d}$ & $\mathrm{b}, \mathrm{c}, \mathrm{d}$ & $\mathrm{a}, \mathrm{c}$ & $\mathrm{a}$ & $\mathrm{a}, \mathrm{c}$ & A & $\mathrm{a}, \mathrm{c}$ & $\mathrm{a}$ & $b, c$ & $\mathrm{~b}, \mathrm{c}$ & $\mathrm{b}, \mathrm{c}$ & $\mathrm{b}, \mathrm{c}$ \\
\hline 3 & $\mathrm{~b}, \mathrm{c}, \mathrm{d}$ & $\mathrm{b}, \mathrm{c}, \mathrm{d}$ & $\mathrm{b}, \mathrm{c}$ & $\mathrm{a}$ & $a, c$ & A & $\mathrm{b}, \mathrm{c}, \mathrm{d}$ & $\mathrm{a}$ & $\mathrm{b}, \mathrm{c}, \mathrm{d}$ & $\mathrm{b}, \mathrm{c}, \mathrm{d}$ & $a, c$ & $\mathrm{~b}, \mathrm{c}$ \\
\hline 4 & $\mathrm{~b}, \mathrm{c}$ & $\mathrm{b}, \mathrm{c}, \mathrm{d}$ & $\mathrm{b}, \mathrm{c}$ & $\mathrm{a}$ & $\mathrm{b}, \mathrm{c}$ & A & $\mathrm{b}, \mathrm{c}, \mathrm{d}$ & $\mathrm{a}$ & $-, \mathrm{c}, \mathrm{d}$ & $\mathrm{b}, \mathrm{c}, \mathrm{d}$ & $\mathrm{b}, \mathrm{c}, \mathrm{d}$ & $\mathrm{b}, \mathrm{c}, \mathrm{d}$ \\
\hline 5 & $\mathrm{~b}, \mathrm{c}$ & $\mathrm{b}, \mathrm{c}, \mathrm{d}$ &,$- c$ & $\mathrm{a}$ & $b, c$ & $\mathrm{a}, \mathrm{c}$ & $-, \mathrm{c}, \mathrm{d}$ & $\mathrm{a}$ & $-, \mathrm{c}, \mathrm{d}$ & $-, \mathrm{c}, \mathrm{d}$ & $\mathrm{b}, \mathrm{c}, \mathrm{d}$ & $\mathrm{b}, \mathrm{c}, \mathrm{d}$ \\
\hline 6 & $\mathrm{~b}, \mathrm{c}$ & $\mathrm{b}, \mathrm{c}, \mathrm{d}$ &,$- c$ & $\mathrm{a}$ & $\mathrm{b}, \mathrm{c}$ & $\mathrm{a}, \mathrm{c}$ & $-, \mathrm{c}, \mathrm{d}$ & $\mathrm{a}$ & & $-, \mathrm{c}, \mathrm{d}$ & $\mathrm{b}, \mathrm{c}, \mathrm{d}$ & $\mathrm{b}, \mathrm{c}$ \\
\hline 7 & $\mathrm{~b}, \mathrm{c}$ & $\mathrm{b}, \mathrm{c}, \mathrm{d}$ & $\mathrm{b}, \mathrm{c}$ & $\mathrm{a}, \mathrm{c}$ & $\mathrm{b}, \mathrm{c}$ & $\mathrm{b}, \mathrm{c}$ & $\mathrm{b}, \mathrm{c}, \mathrm{d}$ & $\mathrm{a}$ & & $-, \mathrm{c}, \mathrm{d}$ & $\mathrm{b}, \mathrm{c}, \mathrm{d}$ & $\mathrm{b}, \mathrm{c}$ \\
\hline 8 & $\mathrm{~b}, \mathrm{c}, \mathrm{d}$ & $\mathrm{b}, \mathrm{c}$ & $\mathrm{b}, \mathrm{c}$ & $\mathrm{a}, \mathrm{c}$ & $\mathrm{b}, \mathrm{c}$ & $\mathrm{b}, \mathrm{c}$ & $\mathrm{b}, \mathrm{c}, \mathrm{d}$ & $\mathrm{a}, \mathrm{c}$ & & $\mathrm{b}, \mathrm{c}$ & $b, c$ & $\mathrm{~b}, \mathrm{c}, \mathrm{e}$ \\
\hline 9 & $\mathrm{~b}, \mathrm{c}, \mathrm{d}$ & $\mathrm{b}, \mathrm{c}$ & $\mathrm{b}, \mathrm{c}$ & $\mathrm{a}, \mathrm{c}$ & $\mathrm{b}, \mathrm{c}$ & $\mathrm{b}, \mathrm{c}, \mathrm{d}$ & $\mathrm{b}, \mathrm{c}, \mathrm{d}$ & $\mathrm{a}, \mathrm{c}$ & & $\mathrm{b}, \mathrm{c}$ & $\mathrm{b}, \mathrm{c}$ & $\mathrm{b}, \mathrm{c}$ \\
\hline 10 & $\mathrm{~b}, \mathrm{c}, \mathrm{d}$ & $\mathrm{b}, \mathrm{c}$ & $\mathrm{a}, \mathrm{c}$ & $\mathrm{a}, \mathrm{c}$ & $\mathrm{a}, \mathrm{c}$ & $\mathrm{b}, \mathrm{c}, \mathrm{d}$ & $\mathrm{b}, \mathrm{c}, \mathrm{d}$ & $\mathrm{a}, \mathrm{c}$ & & $\mathrm{b}, \mathrm{c}$ & $\mathrm{b}, \mathrm{c}$ & $\mathrm{b}, \mathrm{c}$ \\
\hline 11 & $\mathrm{~b}, \mathrm{c}, \mathrm{d}$ & $\mathrm{b}, \mathrm{c}$ & $\mathrm{a}, \mathrm{c}$ & $\mathrm{a}, \mathrm{c}$ & $\mathrm{a}, \mathrm{c}$ & $\mathrm{b}, \mathrm{c}, \mathrm{d}$ & $\mathrm{b}, \mathrm{c}, \mathrm{d}$ & $a, c$ & & $\mathrm{~b}, \mathrm{c}$ & $\mathrm{b}, \mathrm{c}, \mathrm{d}$ & $\mathrm{b}, \mathrm{c}$ \\
\hline 12 & $\mathrm{~b}, \mathrm{c}$ & $\mathrm{b}, \mathrm{c}$ & $\mathrm{b}, \mathrm{c}$ & $\mathrm{a}, \mathrm{c}$ & $\mathrm{b}, \mathrm{c}$ & $\mathrm{b}, \mathrm{c}, \mathrm{d}$ & $\mathrm{b}, \mathrm{c}$ & $\mathrm{a}, \mathrm{c}$ & & $\mathrm{a}, \mathrm{c}$ & $\mathrm{b}, \mathrm{c}, \mathrm{d}$ & $\mathrm{b}, \mathrm{c}$ \\
\hline 13 & $b, c$ & $\mathrm{~b}, \mathrm{c}$ & $\mathrm{b}, \mathrm{c}$ & $\mathrm{a}, \mathrm{c}$ & $\mathrm{b}, \mathrm{c}, \mathrm{d}$ & $\mathrm{b}, \mathrm{c}$ & $b, c$ & $\mathrm{~b}, \mathrm{c}$ & & $\mathrm{a}, \mathrm{c}$ & $\mathrm{a}, \mathrm{c}$ & $\mathrm{b}, \mathrm{c}, \mathrm{d}$ \\
\hline 14 & $b, c$ & $\mathrm{~b}, \mathrm{c}$ & $\mathrm{b}, \mathrm{c}$ & $\mathrm{b}, \mathrm{c}$ & $\mathrm{b}, \mathrm{c}, \mathrm{d}$ & $b, c$ & $b, c$ & $\mathrm{~b}, \mathrm{c}$ & & $\mathrm{a}, \mathrm{c}$ & $\mathrm{a}, \mathrm{c}$ & $-, \mathrm{c}, \mathrm{d}$ \\
\hline 15 & $-, \mathrm{b}, \mathrm{c}, \mathrm{d}$ & $\mathrm{b}, \mathrm{c}$ & $\mathrm{b}, \mathrm{c}$ & $\mathrm{b}, \mathrm{c}$ & $\mathrm{b}, \mathrm{c}, \mathrm{d}$ & $\mathrm{b}, \mathrm{c}$ & $\mathrm{b}, \mathrm{c}$ & $\mathrm{b}, \mathrm{c}, \mathrm{d}$ & & $\mathrm{a}, \mathrm{c}$ & $\mathrm{a}, \mathrm{c}$ & $-, \mathrm{c}, \mathrm{d}$ \\
\hline 16 & $-, \mathrm{b}, \mathrm{c}, \mathrm{d}$ & $\mathrm{b}, \mathrm{c}$ &,$- c$ & $\mathrm{~b}, \mathrm{c}$ & $-, \mathrm{c}, \mathrm{d}$ & $b, c$ & $\mathrm{~b}, \mathrm{c}$ & $-, \mathrm{c}, \mathrm{d}$ & & $\mathrm{a}, \mathrm{c}$ & $\mathrm{a}, \mathrm{c}$ & $\mathrm{b}, \mathrm{c}$ \\
\hline 17 & $-, b, c$ & $\mathrm{~b}, \mathrm{c}$ &,$- c$ &,$- \mathrm{c}$ & $-, \mathrm{c}, \mathrm{d}$ & $\mathrm{b}, \mathrm{c}$ & $b, c$ & $-, \mathrm{c}, \mathrm{d}$ & & $\mathrm{a}, \mathrm{c}$ & $\mathrm{a}, \mathrm{c}$ & $\mathrm{b}, \mathrm{c}$ \\
\hline 18 & $-, b, c$ & $\mathrm{~b}, \mathrm{c}$ & $-, \mathrm{c}, \mathrm{d}$ &,$- \mathrm{c}$ & $\mathrm{b}, \mathrm{c}, \mathrm{d}$ &,$- c$ & $\mathrm{a}$ & & & $\mathrm{a}, \mathrm{c}$ & $\mathrm{a}, \mathrm{c}$ & $\mathrm{b}, \mathrm{c}$ \\
\hline 19 & $-, b, c$ & $\mathrm{a}, \mathrm{c}$ & $-, \mathrm{c}, \mathrm{d}$ &,$- \mathrm{c}$ & $\mathrm{b}, \mathrm{c}$ &,$- c$ & $\mathrm{a}, \mathrm{c}$ & & & $\mathrm{a}, \mathrm{c}$ & $\mathrm{a}, \mathrm{c}$ & $\mathrm{b}, \mathrm{c}, \mathrm{d}$ \\
\hline 20 & $-, b, c$ & $\mathrm{a}, \mathrm{c}$ & $-, \mathrm{c}, \mathrm{d}$ &,$- \mathrm{c}$ & $\mathrm{a}, \mathrm{c}$ &,$- c$ & $\mathrm{a}, \mathrm{c}$ & & & $\mathrm{a}, \mathrm{c}$ & $\mathrm{a}, \mathrm{c}$ & $-, \mathrm{c}, \mathrm{d}$ \\
\hline 21 & $-, b, c$ & $\mathrm{a}, \mathrm{c}$ & $-, \mathrm{c}, \mathrm{d}$ &,$- \mathrm{C}$ & $\mathrm{a}, \mathrm{c}$ &,$- c$ & $\mathrm{a}, \mathrm{c}$ & & & $\mathrm{a}, \mathrm{c}$ & $a, c$ & $\mathrm{~b}, \mathrm{c}, \mathrm{d}$ \\
\hline
\end{tabular}

Keterangan:

- : ikan tidak merespon pakan, sangat pasif, A : aktif, respon pakan cepat, B : pasif, berenang tidak stabil dan di dekat aerasi, respon pakan lambat, $\mathrm{C}$ : lendir berlebih, warna kulit pucat, sirip punggung meregang, $\mathrm{D}:$ sirip ekor geripis, sisik lepas, E : mata menonjol (exopthalmia)

Gejala klinis ikan nila tersaji pada Tabel 2 menunjukkan terjadi perubahan tingkah laku dan morfologi. Gejala klinis pada perlakuan A sebagian besar ikan nila bergerak pasif, berenang tidak stabil dan cenderung mendekati aerasi, respon terhadap pakan yang diberikan lambat, lendir berlebih dihasilkan oleh ikan, warna kulit pucat, sirip punggung meregang, sirip ekor geripis, sisik mengelupas (Gambar 3a, 3b, 3c). Beberapa ikan juga muncul gejala klinis berupa operculum terlihat memerah. Tujuh hari mendekati akhir penelitian, ikan nila masih tidak merespon pakan dengan baik. 


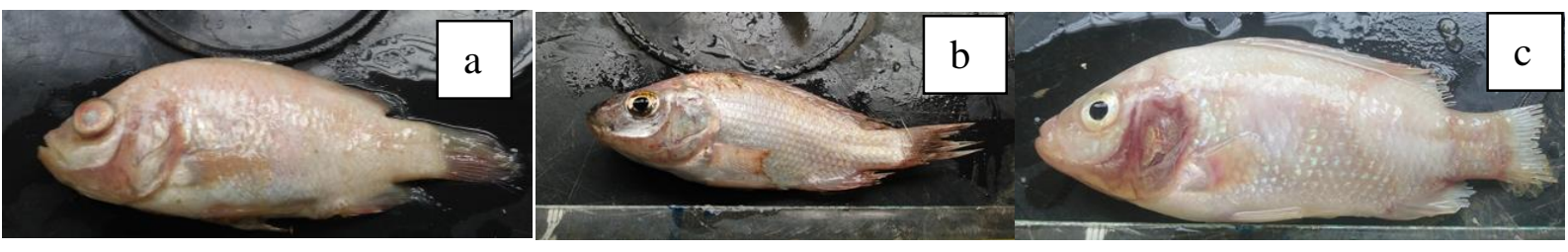

Gambar 3. Gejala Klinis Ikan Nila Selama Penelitian

Keterangan: a. Exopthalmia ; b. Sirip geripis, c. Operculum memerah, Sisik mengelupas

Tabel 3. Gejala klinis yang terjadi selama perlakuan

\begin{tabular}{|c|c|c|c|c|}
\hline No & Organ & Gejala Klinis & Morfologi & Tingkah Laku \\
\hline 1 & Insang & Haemoragi & $\begin{array}{l}\text { Warna merah pada insang dan } \\
\text { operculum }\end{array}$ & $\begin{array}{l}\text { Berenang dipermukaan, } \\
\text { mendekati aerasi dan } \\
\text { pergerakan mulut cepat }\end{array}$ \\
\hline 2 & Sirip & Haemoragi & $\begin{array}{l}\text { Warna memerah pada pangkal } \\
\text { sirip }\end{array}$ & - \\
\hline 3 & Sirip & Geripis & Sirip habis, dan geripis & - \\
\hline 4 & Sisik & Sisik terlepas & Sisik terlepas dari tubuh & - \\
\hline 5 & Otak & $\begin{array}{l}\text { Berenang } \\
\text { abnormal }\end{array}$ & - & $\begin{array}{l}\text { Ikan berenang berputar-putar } \\
\text { (whirling) }\end{array}$ \\
\hline 6 & Abdomen & Dropsy & $\begin{array}{l}\text { Terlihat kembung dan dipenuhi } \\
\text { cairan }\end{array}$ & - \\
\hline 7. & Mata & Exopthalmia & Mata menonjol keluar dan buram & - \\
\hline
\end{tabular}

Ikan nila menunjukkan gejala klinis berupa sirip geripis terjadi di hari ke-2 pada perlakuan A, sedangkan perlakuan D terjadi pada hari ke-4. Hari ke-7,8,9 atau mulai memasuki minggu ke-2 ikan nila semakin menunjukkan perubahan morfologi dan tingkah laku pada perlakuan A yaitu pasif, sirip punggung meregang, sirip geripis, dan ikan mulai pasif ketika diberikan pakan. Gejala klinis perlakuan B sudah mulai terlihat pasif, lendir berlebih, sirip meregang. Perlakuan C menunjukkan adanya ikan yang sudah mulai pasif, berenang dan berkumpul di dekat aerasi dan respon pakan mulai melambat dan morfologi menunjukkan produksi lendir berlebih ini terlihat dari air yang berbuih, warna pucat serta sirip meregang, sedangkan perlakuan D ikan nila mulai berenang pasif dan respon pakan melambat, exopthalmia dan tubuh memucat dan sirip meregang namun pada akhir penelitian beberapa ikan yang tersisa mulau kembali aktif kembali dan merespon pakan dengan baik.

Hari ke-10 dan 11 tidak menunjukkan perubahan dari hari sebelumnya pada perlakuan A, B, C dan D terlihat masih sama gejala yang terjadi seperti adanya perubahan morfologi dan tingkah laku berupa pasif, respon pakan lambat, berenang di atas permukaan mendekati aerasi, lendir berlebih, warna pucat dan sirip punggung meregang. Namun pada hari ke-11 dan 15 tidak ada ikan yang mengalami kematian dari seluruh perlakuan. Kemudian ikan nila perlakuan C pada hari ke-13, 14 dan 15 menunjukkan perubahan gejala klinis berupa ikan tidak merespon pakan, gerak lambat dan sangat pasif, berenang ke arah permukaan air dan mendekati aerasi, dan terlihat juga gejala berenang yang abnormal seperti berenang secara berputar atau wirling hingga pada hari ke-16 dan 17 terjadi kematian yang cukup banyak hingga 4-5 ekor ikan yang mati sekaligus. Perlakuan B tidak mengalami perubahan gejala klinis dari hari sebelumnya namun pada 7 hari sebelum penelitian berakhir, perlakuan mengalami perubahan gejala klinis ikan yang semakin pasif dan respon pakan semakin buruk sehingga juga mengalami kematian yang cukup tinggi yakni 4-5 ekor pada hari ke-20 dan 21, sedangkan pada minggu terakhir ikan yang tersisa pada perlakuan D menunjukkan ikan sudah mulai aktif kembali berenang secara normal, dan ketika diberikan pakan ikan merespon dengan baik.

\section{Kualitas Air}

Hasil pengukuran kualitas air selama penelitian pada semua perlakuan tersaji pada Tabel 4.

Tabel 4. Kisaran Parameter Kualitas Air Media Pemeliharaan Ikan Nila (O. niloticus) Selama Penelitian

\begin{tabular}{|c|c|c|c|c|c|}
\hline \multirow{2}{*}{ Parameter } & \multicolumn{4}{|c|}{ Perlakauan } & \multirow{2}{*}{ Kisaran Optimum } \\
\hline & $\mathrm{A}$ & $\mathrm{B}$ & $\mathrm{C}$ & $\mathrm{D}$ & \\
\hline $\mathrm{DO}(\mathrm{mg} / \mathrm{L})$ & $3,3-3,4$ & $3,2-3,4$ & $3,2-3,5$ & $3,4-3,5$ & $\geq 3^{\text {a) }}$ \\
\hline Suhu $\left({ }^{\circ} \mathrm{C}\right)$ & $24-26$ & $23-26$ & $23-26$ & $23-25$ & $25-32^{a)}$ \\
\hline $\mathrm{pH}$ & $6-7$ & $6-7$ & $6-7$ & $5-6$ & $6,5-8,5^{\mathrm{a})}$ \\
\hline
\end{tabular}

Keterangan :

a) SNI (2009) 
Kualitas air untuk suhu dan $\mathrm{pH}$ masih belum berada dalam kisaran optimum dan layak namun untuk DO masih terbilang layak untuk digunakan dalam media pemeliharaan ikan nila. Meskipun demikian, kadar suhu dan pH yang masih belum berada dalam kisaran layak selama penelitian ini terjadi dikarenakan cuaca yang tidak menentu pada saat penelitian. Selama penelitian tidak dilakukan pergantian air sama sekali pada akuarium perlakuan.

\section{PEMBAHASAN}

Bakteri B. methylotrophicus dalam uji in vitro yakni uji zona hambat dan uji tumbuh bersama didapatkan hasil bahwa bakteri B. methylotrophicus dapat menghambat pertumbuhan bakteri A. hydrophila. Hal ini terbukti dengan adanya zona hambat (zona bening) yang dihasilkan pada kertas cakram (Gambar 1). Konsentrasi $B$. methylotrophicus dengan zona hambat paling besar yakni sebesar $10^{9} \mathrm{CFU} / \mathrm{mL}$ dengan rerata zona hambat $24,49 \pm 4,2 \mathrm{~mm}$ kemudian pada kepadatan $10^{7} \mathrm{CFU} / \mathrm{mL}$ dengan rerata zona hambat $15,2 \pm 2,63 \mathrm{~mm}$, kepadatan $10^{6}$ $\mathrm{CFU} / \mathrm{mL}$ dengan zona hambat $8,5 \pm 0,2 \mathrm{~mm}$ dan kepadatan $10^{8} \mathrm{CFU} / \mathrm{mL}$ rerata zona hambatnya yaitu $8 \pm 1,7 \mathrm{~mm}$. Kemampuan daya hambat B. methylotrophicus terhadap A. hydrophila dapat dikatakan kuat (sensitif) pada kepadatan probiotik $10^{9} \mathrm{CFU} / \mathrm{mL}$, sedang (intermediet) untuk kepadatan probiotik $10^{7} \mathrm{CFU} / \mathrm{mL}$, dan lemah (resisten) untuk kepadatan probiotik $10^{8}$ dan $10^{6} \mathrm{CFU} / \mathrm{mL}$. Hal ini sesuai dengan pernyataan Afnidar (2014), bahwa diameter zona hambat yang menunjukkan hasil lebih besar dari $20 \mathrm{~mm}$, maka dapat dikatakan respon hambatan pertumbuhannya tergolong kuat (sensitif). Hasil pengukuran zona hambat 16-20 mm maka hambatan pertumbuhannya tergolong sedang (intermediet) dan apabila hasil pengukuran sebesar 1-15 mm hambatan pertumbuhannya tergolong lemah (resisten), dan jika $0 \mathrm{~mm}$ maka tidak ada respon hambatan pertumbuhan yang terjadi. Terbentuknya zona hambat yang besar pada kepadatan B. methylotrophicus $10^{9} \mathrm{CFU} / \mathrm{mL}$ menunjukkan adanya interaksi antagonis yang terjadi antara bakteri kandidat probiotik dengan A. hydrophila. Interaksi ini dapat berkaitan karena adanya persaingan nutrisi media pertumbuhan bakteri dan adanya senyawa antimikroba atau bakteriosin yang diproduksi oleh B .methylotrophicus. Desriac et al. (2010) menyatakan secara umum, bakteri menghasilkan beberapa jenis senyawa anti-mikroba atau bakteriosin untuk menghambat atau membunuh spesies bakteri pesaing lainnya. Hal ini diperkuat oleh Sorokulova et al. (2007) yang menyatakan bahwa probiotik dari golongan Bacillus telah banyak diaplikasikan untuk kepentingan bioteknologi termasuk jenis enzim dan asam amino yang dihasilkan serta produksi antibiotik untuk fermentasi dan pengendalian patogen.

B. methylotrophicus mampu menghambat A. hydrophila yang merupakan bakteri Gram negatif hal ini diperkuat pula oleh Sharma et al. (2013) yang diketahui bahwa B. methylothrophicus mampu secara aktif menghambat bakteri patogen baik Gram positif, maupun Gram negatif. Dikarenakan mengandung lipopeptida siklik dengan kisaran yang luas. Polipeptida merupakan polimer yang tersusun dari beberapa peptida hasil pengikatan gugus karboksil $(\mathrm{COOH})$ dengan gugus amino. Satu atau lebih polipeptida dapat membentuk protein, contohnya enzim. Polipeptida terbentuk melalui proses ekspresi gen yang terjadi di dalam sel. Iturin dan surfaktin adalah contoh antibiotik yang dapat menghambat pertumbuhan jamur (Huang et al., 1993). Lebih lanjut Jemil et al. (2017) menjelaskan karakter struktural dan identifikasi dari lipopeptida siklik yang dihasilkan $B$. methylotrophicus DCS1. Sampel lipopeptida sederhana dari B. methylotrophicus tersusun sekitar $40 \%$ protein. Berbagai asam amino terdeteksi pada lipopeptida kasar DCS1 (B. methylotrophicus), sebagian besar asam amino yang menyusun komposisi lipopeptida termasuk dalam keluarga surfaktin, iturin dan fengycin. Surfaktin adalah antibiotik yang memiliki kerja sebagai suatu biosurfaktan, surfaktin dapat merusak permeabilitas membran sel dengan cara menurunkan tegangan permukaan (Huang et al., 1993).

Kelulushidupan atau survival rate tertinggi hingga terendah pada akhir masa pemeliharaan adalah perlakuan D (penambahan B. methylothrophicus 7 hari sekali) sebesar 13,33\% diikuti perlakuan A ( tidak ditambahkan B. methylothrophicus) 6,67\%, perlakuan C (penambahan B. methylothrophicus 5 hari sekali) dan B (penambahan B. methylothrophicus 3 hari sekali) sebesar 3,33\%. Hasil uji analisis ragam data kelulushidupan menunjukkan bahwa penambahan bakteri $B$. methylothrophicus pada media budidaya ikan nila dengan frekuensi pemberian yang berbeda tidak berpengaruh nyata terhadap kelulushidupan ikan nila (O. niloticus) yang terinfeksi oleh bakteri $A$. hydrophila melalui media budidaya atau air $(\mathrm{P}>0,05)$. Hal ini diduga karena menurunnya efektifitas bakteri probiotik yang disebabkan frekuensi pemberian probiotik yang terlalu sering sehingga menambah konsentrasi bakteri pada media pemeliharaan dan menyebabkan keseimbangan bakteri pada media pemeliharaan terganggu. Konsentrasi bakteri yang terlalu tinggi juga dapat mengakibatkan persaingan nutrisi, oksigen maupun ruang diantara sesama bakteri probiotik yang ditambahkan. Dugaan ini diperkuat oleh Sya;bani et al. (2015),yang menyatakan bahwa pemberian probiotik yang dilakukan secara terus menerus dapat menurunkan keefektifannya, sehingga pemberian probiotik dengan waktu yang berselang akan lebih efektif dan dapat menghasilkan sistem imun yang lebih baik karena setiap probiotik yang masuk ke dalam tubuh dapat langsung merangsang aktifnya sistem imun. Nikoskelainen et al. (2001) juga menyatakan bahwa penggunaan probiotik dalam konsentrasi tinggi ternyata tidak menjamin perlindungan yang lebih baik terhadap inang.

Perkembangan jumlah populasi total bakteri yang terdapat pada media pemeliharaan di akhir penelitian menunjukkan angka $10^{12} \mathrm{CFU} / \mathrm{mL}$ pada perlakuan A, kemudian pada perlakuan B adalah $10^{17} \mathrm{CFU} / \mathrm{mL}$ dan $\mathrm{C}$ adalah $10^{15} \mathrm{CFU} / \mathrm{mL}$, sedangkan pada perlakuan D menunjukkan angka $10^{17} \mathrm{CFU} / \mathrm{mL}$. Perbandingan jumlah $A$. 
hydrophila dengan bakteri keseluruhan didalam air pada hari ke-1 adalah 1:10 ${ }^{3}$ untuk perlakuan A, Perlakuan B $1: 10^{9}$, sedangkan perlakuan C, D adalah $1: 10^{8}$. Jumlah bakteri ini belum menyebabkan munculnya gejala klinis pada ikan nila selama hari ke-1, namun terjadi kematian pada perlakuan B dan C pada hari ke 1, kemudian pada hari ke-2 dan ke 3 ikan nila perlakuan A dan D mulai menunjukkan gejala klinis berupa sirip geripis, dan ikan mulai berenang ke permukaan mendekati aerasi, dan mulai terjadi kematian pada perlakuan A, C, dan D Hari ke15 menunjukkan nilai $1: 10^{7}$ untuk perlakuan A, perlakuan B 1:10 ${ }^{12}$ dan sama sama tidak terjadi kematian, C 1:10 ${ }^{10}$ dengan jumlah kematian ikan 2 ekor, perlakuan D adalah $1: 10^{14}$ tidak ada kematian ikan dari perlakuan D. Hari ke-21 (akhir penelitian) menunjukkan nilai 1:106 untuk perlakuan A dan menyebabkan 1 kematian ikan, perlakuan B 1:10 ${ }^{10}$ dan menyebabkan kematian 5 ekor ikan. Perlakuan C 1:10 12 dengan jumlah kematian ikan 1 ekor, perlakuan D adalah 1:10 12 menyebabkan kematian 1 ekor ikan. Nilai ini menunjukkan populasi bakteri pada media yang tertinggi adalah perlakuan D yang diduga karena adanya interaksi antar B. methylotrophicus dengan bakteri lain diduga dapat membuat resiko terjadinya kematian akibat serangan A. hydrophila dapat sedikit tertunda.. Konsentrasi bakteri B. methylotrophicus yang tinggi pada perlakuan D menyebabkan kematian yang lebih rendah dibandingkan dengan perlakuan yang lain. Hal ini diduga dikarenakan bakteri dalam air dengan konsentrasi yang tinggi dapat menekan $A$. hydrophila sehingga tidak dapat menyebabkan kematian diduga hal ini terjadi karena bakteri tersebut berperan menghasilkan senyawa anti bakteri ataupun dengan cara menjadi pesaing bagi $A$. hydrophila. Selain itu, diduga kandungan surfaktin dan iturin pada B. methylotrophicus menyebabkan lisisnya bakteri lain termasuk A. hydrophila. Hal ini diperkuat oleh Balcazar et al. (2004),yang menyatakan bahwa bakteri bacillus menghasilkan beberapa zat antimikroba atau produk ekstraseluler yang dapat menghambat pertumbuhan dari bakteri A hydrophila diantaranya adalah bakteriosin, subtilin, koagulin, dan antibiotik surfaktan, iturins dan basilin. Lang \& Wagner (1993) menyatakan bahwa surfaktin yang merupakan lipopeptida siklik selain berfungsi menurunkan tegangan permukaan zat cair juga merusak sferoplas serta protoplas bakteri lain yang berada di dekat bakteri penghasilnya.

Perkembangan jumlah populasi A. hydrophila tanpa pemberian B. methylotrophicus (perlakuan A) pada akhir penelitian adalah $10^{5} \mathrm{CFU} / \mathrm{mL}$, sedangkan jumlah populasi $A$. hydrophila pada perlakuan pemberian $B$. methylotrophicus setiap 3 hari (perlakuan B) adalah $10^{6} \mathrm{CFU} / \mathrm{mL}$, pada perlakuan pemberian B. methylotrophicus setiap 5 hari (perlakuan $\mathrm{C}$ ) adalah $10^{2} \mathrm{CFU} / \mathrm{mL}$, pada perlakuan pemberian $B$. methylotrophicus setiap 7 hari (perlakuan D) adalah $10^{3} \mathrm{CFU} / \mathrm{mL}$. Hal ini diduga terjadi disebabkan adanya senyawa ekstraseluler yang dihasilkan oleh Bacillus. Penelitian lain juga menyebutkan bahwa secara in vitro, probiotik Bacillus dapat menghambat pertumbuhan A. hydrophila (Sansawat \& Thirabuyanon, 2009). Senyawa ekstraseluler yang dihasilkan oleh Bacillus, antara lain esterase lipase, leucine arylamidase, acid phosphatase, lipase, naphthol- ASBI-phospholidase, subtilin, coagulin, surfaktin, iturin, dan bacilysin (Murilio \& Villamil, 2011). Surfaktin dan iturin inilah yang secara aktif merusak permeabilitas membran dari bakteri A.hydrophila.

Ikan nila pada hari ke-1 pasca dimasukkan pada media air menunjukkan ikan tetap aktif dan respon pakan cepat pada perlakuan A (kontrol), dan perlakuan B, C, D belum menunjukkan gejala klinis perubahan morfologi hingga hari ke-2. Ikan nila mulai menunjukkan gejala klinis hari ke-3 dan ke-4 perlakuan A menunjukkan ikan pasif, respon pakan lambat, berenang tidak stabil di dekat aerasi, lendir berlebih, warna kulit pucat, sirip punggung meregang, dan terlihat sisik mulai lepas, terdapat hemoragik pada beberapa bagian tubuh seperti operculum dan ekor geripis terlihat pada ikan yang mati. Gejala klinis tingkah laku ini sesuai dengan Hardi et al. (2014) gejala klinis ikan nila yang terinfeksi A. hydrophila melalui perendaman yakni ikan mengalami berenang gasping (berenang tegak dibawah permukaan air), berenang di dasar akuarium, sisik lepas, sirip geripis, gerak reflek lambat, gerakan operculum cepat cenderung mendekati aerasi, exopthalmia, haemoragi dan nafsu makan yang menurun.

Hari ke- 5 hingga ke 14, pada perlakuan A beberapa ikan pasif, lendir berlebih, warna kulit pucat, sirip geripis, pangkal ekor mulai terlihat merah, namun masih terdapat ikan yang aktif dan tubuh pucat. Ikan nila perlakuan B pasif, respon pakan lambat, beberapa ikan masih berenang mendekati aerasi, lendir berlebih, warna pucat, namun sebagian besar aktif, respon pakan cepat. Ikan nila perlakuan C sebagian besar aktif, respon pakan mulai pasif, ikan pucat, sirip geripis, dan ada juga yang pasif bereanang di dasar akuarium, sedangkan perlakuan D perubahannya adalah kulit pucat, lendir berlebih, dan sirip geripis pada beberapa ikan, dan ada yang mengalami mata membesar (exopthalmia) pada ikan yang mati. Hari ke-14,15,16 ikan nila semakin menunjukkan perubahan morfologi dan tingkah laku pada perlakuan A yaitu pasif, sirip punggung meregang, sirip geripis, dan beberapa ikan yang mati operculum nya terlihat memerah atau terkena Haemoragi. Gejala klinis haemoragi diduga diakibatkan karena adanya toksik yang disebabkan oleh A. hydrophila yaitu toksin hemolisin. Hal ini juga diperkuat juga oleh Chopra et al. (2000) Luka dan hemoragik yang terjadi pada tubuh ikan diduga disebabkan oleh toksin ekstraselular yang bekerja bersinergi merusak jaringan pada tubuh ikan. Hemolisin yang dihasilkan oleh bakteri tersebut bekerja memecah dan melisiskan sel-sel darah merah. Hal tersebut terlihat dengan adanya luka dan pendarahan pada tubuh ikan.

Hari ke-17 dan 19 tidak menunjukkan perubahan dari hari sebelumnya pada perlakuan A, B dan C, sedangkan perlakuan D ikan ikan yang masih tersisa menunjukkan adanya perubahan morfologi dan tingkah laku berupa aktif kembali, respon pakan membaik, berenang normal namun masih mendekati aerasi, lendir berlebih, 
warna pucat dan sirip punggung masih meregang. Kemudian ikan nila perlakuan A,B, dan C pada hari ke-20, dan 21 menunjukkan perubahan gejala klinis berupa ikan tidak merespon pakan, gerak lambat dan sangat pasif. Perlakuan D beberapa ikan masih menunjukkan lendir berlebih, pucat, pasif, sirip geripis, namun beberapa ikan ada yang sudah normal kembali. Gejala klinis pada akhir perlakuan ini menunjukkan adanya proses recovery karena beberapa ikan yang masih tersisa (hidup) sudah mulai aktif dan respon pakannya membaik, hanya saja beberapa ikan nila juga terlihat masih pasif.

Hasil nilai kualitas air pada media pemeliharaan pada beberapa variabel seperti suhu bagi bakteri $B$. methylothrophicus masih dalam kondisi bisa untuk tumbuh namun belum mencapai nilai suhu optimum bagi $B$. methylothrophicus untuk tumbuh secara optimum, namun untuk nilai $\mathrm{pH}$ yang didapat selama masa pemeliharaan masih tergolong baik karena nilai optimum bagi B. methylothrophicus untuk tumbuh yakni pada nilai $\mathrm{pH}$ 6. Hal ini diperkuat oleh Ngoc et al. (2016) yang menyatakan bahwa kondisi kultur yang optimum bagi $B$. methylothrophicus teridentifikasi pada suhu $30^{\circ} \mathrm{C}$ dan $\mathrm{pH}$ 6. Sementara hasil kualitas air terutama pada variabel suhu masih dalam kisaran yang baik bagi bakteri $A$. hydrophila untuk tumbuh karena kisaran yang didapat yakni berkisar antara $23-26{ }^{\circ} \mathrm{C}$ A. hydrophila memiliki rentang suhu yang cukup tinggi untuk tumbuh sesuai dengan Olga (2012) bahwa bakteri $A$. hydrophila dapat ditemukan dimana-mana, terutama di perairan yang mengandung bahan organik tinggi. Disamping itu, bakteri ini dapat tumbuh pada suhu $4-45^{\circ} \mathrm{C}$, meskipun lambat dan tumbuh optimum pada suhu $37^{\circ} \mathrm{C}$

\section{KESIMPULAN DAN SARAN}

\section{Kesimpulan}

1. Penggunaan bakteri kandidat probiotik B. methylothrophicus dalam media budidaya dapat mengontrol kepadatan bakteri $A$. hydrophila dalam media pemeliharaan pada akhir penelitian tertinggi $10^{5} \mathrm{CFU} / \mathrm{ml}$ pada perlakuan A, dan B, Perlakuan D $10^{3} \mathrm{CFU} / \mathrm{ml}$ dan terendah $10^{2} \mathrm{CFU} / \mathrm{ml}$ pada perlakuan $\mathrm{C}$ namun masih belum optimum;

2. Penggunaan bakteri kandidat probiotik B. methylothrophicus dalam media budidaya dapat menghambat atau menekan kepadatan A. hydrophila dalam media pemeliharaan. Terlihat pada perlakuan C dan D kelimpahan bakteri $A$. hydrophila mulai dari pertengahan masa pemeliharaan hingga akhir masa pemeliharaan hanya berkisar tidak lebih dari $10^{3}-10^{5} \mathrm{CFU} / \mathrm{ml}$;

3. Penggunaan bakteri kandidat probiotik B. methylothrophicus dalam media budidaya tidak menunjukkan pengaruh yang nyata terhadap kelulushidupan ikan nila yang dipelihara selama 21 hari, namun pemberian bakteri kandidat probiotik B. methylothrophicus dapat meningkatkan SR dari ikan nila 6,66 \% dibandingkan SR perlakuan kontrol yang tidak ditambahkan bakteri B. methylothrophicus.

\section{Saran}

1. Penentuan rentang frekuensi penambahan bakteri kandidat probiotik B. methylothrophicus untuk mengetahui frekuensi penambahan yang terbaik pada pemeliharaan ikan nila;

2. Disarankan penelitian lebih lanjut tentang penambahan bakteri kandidat probiotik B. methylothrophicus pada media budidaya ikan nila dengan perhitungan kepadatan setiap hari sehingga dapat lebih terlihat bagaimana pertumbuhan dari A. hydrophila yang lebih baik.

\section{UCAPAN TERIMA KASIH}

Terima kasih penulis ucapkan kepada APBN DPA SUKPA Fakultas Perikanan dan Ilmu Kelautan, Universitas Diponegoro, yang telah mendanai sepenuhnya penelitian ini.

\section{DAFTAR PUSTAKA}

Afnidar. 2014. Fitokimia dan Uji Aktivitas Antibakteri Ekstrak Kalus Tumbuhan Sernai (Wedelia biflora (L)Dc.). J. JESBIO. 3(4), ISSN: 2302-1705.

Agustina, P. A.H.C, Haditomo. Sarjito. 2018. Penambahan Bakteri Kandidat Probiotik (Bacillus methylothrophicus) Dengan Konsentrasi Berbeda Pada Media Budidaya Ikan Nila (Oreochromis niloticus) Untuk Pencegahan Serangan Aeromonas hydrophila. [SKRIPSI]. Universitas Diponegoro. 85 hlm.

Andriani, R. 2016. Pengenalan Alat-Alat Laboratorium Mikrobiologi Untuk Mengatasi Keselamatan Kerja dan Keberhasilan Praktikum. J Mikrobiologi 1(1) ISSN : O1A114084.

Balcazar JL, de-Blas I, Ruiz-Zarzuela I, Vendrell D, Muzquiz JL. 2004. Probiotics: a tool for the future of fish and shellfish health management. J. of Aquaculture in the Tropics. 19: 239-242.

Chopra A, K. X, J, Xu. D, Ribardo. M, Gonzalez. K, Kuhl. J, W, Peterson. C, W, Houston. 2000. The Cytotoxic Enterotoxin of Aeromonas hydrophila Induces Proinflammatory Cytokine Production and Activates Arachidonic Acid Metabolism in Macrophages. J. Infection and Immunity. 68(5). Page : 2808-2818.

Das,S. K, Mondal. Salma, H. 2017. A review on application of probiotic, prebiotic and synbiotic for sustainable development of aquaculture. J of Entomology and ZoologyStudies. 5(2): 422-429. 
Desriac, F., Defer, D., Bourgougnon, N., Brillet, B., Chevalier, P.L., Fleury, Y., 2010. Bacteriocin as Weapons in the Marine Animal-Associated Bacteria Warfare: Inventory and Potential Applications as an Aquaculture Probiotic. Mar. Drugs, 8: 1153-1177.

Esteban,M,A. H. Cordero. M, M,Tom. A,M, J,Monreal. A, Bakhrouf. A, Mahdhi. 2014. Effect of dietary supplementation of probiotics and palm fruits extracts on the antioxidant enzyme gene expression in the mucosae of gilthead seabream (Sparus aurata L.). J Fish \& Shellfish Imunology :1-9.

Farias, T.H.V., Levy-Pereira, N., L.D.O. Alves, D.D.C. Dias, L. Tachibana, F. Pilarski, M.A.D.A. Belo, M.J.T.Ranzani-Paiva. 2016. Probiotic Feeding Improves The Immunity of Pacus, Piaractusmesopotamicus, during Aeromonas hydrophila Infection. Animal Feed Science and Technology, 211: 137-144.

Garde, C, Thomas. B, M. Givskov, T. H. Jakobsen, M. Hentzer, A. Claussen, Kim. S, Jesper. F, T. Sams. 2010. Quorum Sensing Regulation in Aeromonas hydrophila. J. Mol. Biol. 396 : 49-857. doi:10.1016/j.jmb.2010.01.002.

Haditomo, A.H.C., A.M. Lusiastuti, Widanarni. 2016. Studi Bacillus Firmus Sebagai Kandidat Probiotik Dalam Menghadapi Aeromonas hydrophila PADA Media Budidaya. J Saintek Perikanan, 11 (2): 111-114.

Haditomo, A.H.C., Sarjito, Desrina, S.B. Prayitno, 2017. $10^{\text {th }}$ Symposium On Disease in Asian Aquaculture (DAA 10), 28 Agustus 2017-1 September 2017, Bali, Indonesia. Screening of Isolated Potential Probiotic from Mud Aquaculture in Central Java Indonesia with Molecular Based.

Hardi, E, H. Catur A, P. Triesna H. Rizki T, H. 2014. Infeksi Aeromonas hydrophila Melalui Jalur yang Berbeda Pada Ikan Nila (Oreochromis niloticus) Di Loa Kulu Kutai Kartanegara Kalimantan Timur. J. Kedokteran Hewan. 8 (2), ISSN : $1978-225 X$.

Huang, C.H., T. Ano, and M. Shoda. 1993. Nucleotide sequence and characteristics of the gene, lpa-14, responsible for biosynthesis of the lipopeptide antibiotics iturin A and surfactin from Bacillus subtilis RB14. J of Fermentation and Bioengineering 76: 445-450.

Jemil, N., A.Manresa, F.Rabanal, H.B.Ayed, N.Hmidet, M.Nasri. 2017. Structural Characterization And Identification Of Cyclic Lipopeptides Produced by Bacillus methylotrophicus DCS1 strain. J of Chromatography B, 1060: 374-386.

Kementerian Kelautan dan Perikanan. 2013. Statistik Menakar Target Ikan Air Tawar. Direktorat Jenderal Perikanan Budidaya. Jakarta.

Lang, S. \& F. Wagner. 1993. Bioconversion of Oils and Sugars to Glycolipids. Dalam Kosaric N, editor. Biosurfactans. Production. Properties. Application. Marcel Dekker. New York. Hlm 346-382.

Murilio I., L. Villamil. 2011. Bacillus cereus and Bacillus subtilis Used as Probiotics in Rotifer Branchionus plicatilis Cultures. J of Aquaculture Research and Development,07: 1-5.

Ngoc, N, N. Nguyen V, C. Tran L, H. Pham T, T, G. 2016. Microbiologycal Characterization and Potential Application of Indigenous B. methylotrophycus Ba1 in Handling of Canna edulis. Ker Processing Craft Village Wastewater. J Of Forest Science and Technology No. 5. Page: 4-9.

Nikoskelainen, S., Ouwehand, A., Salminen, S., \& Bylund, G. 2001. Protection of Rainbow Trout Onchorhyncus mykiss from furunculosis by Lactobacillus rhamnosus. Aquaculture, 198: 229-236.

Olga. 2012. Patogenisitas Bakteri Aeromonas hydrophila Asb01 Pada Ikan Gabus (Ophicephalus striatus). J Sains Akuatik 14 (1): 33 - 39

Sansawat A, Thirabunyanon M. 2009. Anti- Aeromonas hydrophila Activity and Characterisation of Novel Probiotics Strains of Bacillus subtilis Isolated from the Gastrointestinal tract of Giant Freshwater Prawns. Maejo International J of Science and Technology, 3: 77-87.

Sharma S.C.D., M.S.Shovon, M.G.S. Jahan, A.K.M. Asaduzzaman, Md. A.Rahman, K.K. Biswas, N. Abe, N.Roy. 2013. Antibacterial And Cytotoxic Activity of Bacillus methylotrophicus-SCS2012 Isolated From Soil. J of Microbiology, Biotechnology and Food Sciences, 2 (4): 2293-2307.

SNI 7550. 2009. Produksi ikan Nila (Oreochromis niloticus Bleeker) kelas Pembesaran di Kolam Air Tenang. 5 hlm.

Sorokulova, I. B. Iryna V, P. Muriel D. Irina G, O. Jen M, H. Simon M, C. Maria C. Urdaci. 2007. The Safety Of Two Bacillus Probiotic Strains For Human Use. J. Dig Dis Sci. 53:954-963. DOI 10.1007/s10620-0079959-1.

Sya'bani, N. Ayi, Y. Ike, R. A, M, Lusiastuti. 2015. Frekuensi Penambahan Probiotik Bacillus sp dan Staphylococcus sp pada Media Pemeliharaan Benih Ikan Lele Dumbo (Clarias gariepinus) untuk Ketahanan Terhadap Aeromonas hydrophila. J, Perikanan Kelautan. 6(2). Hal : 130-140.

Ulkhaq, M. F. Widanarni., A.M. Lusiastuti. 2014. Aplikasi Probiotik Bacillus Untuk Pencegahan Infeksi Aeromonas hydrophilla Pada Ikan Lele. J Akuakultur Indonesia 13 (2) : 105-114. 